\title{
Program Pelatihan dan Pengembangan : Manfaatnya bagi Pegawai dan Organisasi Koperasi
}

\author{
${ }^{1}$ Arman Maulana, ${ }^{2}$ Soeganda Priyatna, ${ }^{3}$ Husen Saeful Insan, ${ }^{4}$ Helmawati \\ ${ }^{1,3,4}$ Universitas Islam Nusantara \\ ${ }^{2}$ Universitas Pasundan \\ 1armandjexo@gmail.com \\ ${ }^{2}$ soeganda_priyatna@yahoo.com \\ 3huseninsan@gmail.com \\ helmawati.dr@gmail.com
}

\begin{abstract}
ABSTRAK
Tujuan dari penelitian ini adalah untuk menyajikan studi kepustakaan dan observasi yang didirikan pada program pelatihan dan pengembangan pegawai serta manfaatnya koperasi jajaran Dekopinda Kota Cimahi. Penelitian ini menganalisis struktur dan elemen program pelatihan dan pengembangan pegawai dan kemudian studio ini menyajikan apa hasil positif bagi pegawai dan Organisasi. Organisasi merasa sulit untuk tetap kompetitif dalam ekonomi global baru-baru ini. Pentingnya plan pengembangan pegawai tumbuh bagi Organisasi yang mengejar untuk menerima keunggulan di antara pesaing. Pegawai adalah sumber daya Organisasi yang terhormat dan keberhasilan atau kegagalan Organisasi bergantung pada kinerja pegawai. Oleh karena itu,organisasi membiayai sejumlah besar program pelatihan dan pengembangan pegawai. Selanjutnya, dalam program pelatihan sangat mendukung bagi perusahaan untuk menekankan pada pengetahuan, keahlian dan kemampuan pegawai. Ada substansial di antara para profesional dan peneliti tentang pengaruh program pengembangan terhadap pegawai dan Organisasi. Studi yang dijelaskan di sini adalah penilaian literatur tentang dasar program pengembangan pegawai dan manfaatnya bagi organisasi dan pegawai.
\end{abstract}

Kata kunci: Desain pelatihan, komponen pelatihan, manfaat pelatihan.

\section{ABSTRACT}

The purpose of this study is to present a literature study and observation that was established in the employee training and development program as well as the benefits of cooperatives in the ranks of the Cimahi City Dekopinda. This study analyzes the structure and elements of employee training and development programs and then this studio presents what are the positive results for employees and the Organization. Organizations find it difficult to stay competitive in the recent global economy. The importance of employee development plans is growing for Organizations seeking to gain an edge over competitors. Employees are a respected resource of the Organization and the success or failure of the Organization depends on the performance of the employees. Therefore, the organization finances a large number of employee training and development programs. Furthermore, the training program is very supportive for companies to emphasize the knowledge, skills and abilities of employees. There is substantial interest among professionals and researchers about the impact of development programs on employees and the organization. The study described here is an assessment of the literature on the basis of employee development programs and their benefits to organizations and employees.

Keywords: Training design, training components, training benefits.

\section{PENDAHULUAN}

Pada tahun 1970-an, upaya perencanaan dan pengembangan karir terutama ditujukan pada pegawai muda yang memiliki potensi tinggi. Disarankan bagi organisasi untuk membuat rencana masa depan dan memberikan pelatihan dan pengembangan kepada pegawai baru untuk posisi tinggi di masa depan (Dwivedi, 2006). Namun, model jalur karir berkembang dengan sangat baik melalui komitmen konservatif yang akan ditawarkan pegawai kepada organisasi pegawai. Komitmen ini dapat digambarkan sebagai kesepakatan emosional dimana manajer umumnya menjamin loyalitas untuk komitmen jangka panjang dengan organisasi sebagai hasil dari memberikan keselamatan kerja pegawai dalam organisasi, kesempatan untuk kemajuan karir pegawai, dan kesempatan pelatihan (Gerosa, 2015). Sejumlah organisasi tertentu mengadopsi cara yang sama untuk melatih pegawai nya. Oleh karena itu, saat ini organisasi ditekankan pada pelatihan dan 
pengembangan pegawai agar dapat memberikan dampak yang baik terhadap organisasi.

Di setiap sektor, pencapaian organisasi mana pun sangat bergantung pada pegawainya. Namun, ada aspek lain yang berbeda yang melakukan bagian utama, sebuah organisasi perlu memastikan pegawai yang efisien sejalan dengan finansial dominan dan kompetitif di pasar. Oleh karena itu untuk mempertahankan sumber daya manusia yang berharga ini, organisasi harus sadar tentang kepuasan kerja dan retensi pegawai. Beberapa organisasi berpikir bahwa pegawai hanya mencari keuntungan finansial dari pekerjaan pegawai. Pernyataan ini mengabaikan signifikansi tinggi bahwa sebagian besar pegawai ditempatkan di sana diri pada manfaat yang melekat pada profesi pegawai. Akibatnya, tidak hanya kepuasan kerja pegawai dan retensi tetapi memiliki efek yang tidak diinginkan pada organisasi. Setiap organisasi harus memiliki pegawai yang mampu dengan cepat menyesuaikan diri dalam lingkungan bisnis yang terus berfluktuasi. Saat ini sebagian besar perusahaan menginvestasikan banyak uang untuk pelatihan dan pengembangan pegawai agar tetap kompetitif dan berhasil menjadi bagian dari organisasi. Pentingnya pelatihan bagi pegawai berkembang pesat dan organisasi menggunakan alat ini untuk bersaing dengan pesaing pegawai di pasar.

Penelitian yang dilakukan Rizeria (2018) bahwa program pelatihan dan pengembangan memiliki dampak yang efektif pada tujuan pegawai dan organisasi koperasi. Beberapa ahli menyarankan bahwa peluang pelatihan meningkatkan pergantian pegawai yang tinggi sedangkan yang lain mengklaim bahwa pelatihan adalah instrumen yang bermanfaat untuk reorganisasi pegawai koperasi (Djamaludin, 2010). Maka dari itu pelatihan pegawai adalah praktik sumber daya manusia yang rumit yang secara ekspresif dapat mempengaruhi pencapaian organisasi. Selain itu, organisasi berjuang untuk mendapatkan kesuksesan dalam ekonomi dunia, mencoba membedakan berdasarkan kemampuan, informasi, dan antusiasme tenaga kerja pegawai.

Banyak nya koperasi khususnya di jawa barat pada tahun 2018 menurut Badan Pusat Statistik Provinsi Jawa Barat, Dinas Koperasi dan UMKM Provinsi Jawa Barat dengan nilai 24.727 koperasi umum, 670 koperasi unit desa dan 24.057 koperasi non KUD. Perkembangan koperasi memang menggembirakan, namun bukan berarti tidak ada koperasi yang tidak aktif atau koperasi yang gagal. Ada banyak alasan yang menyebabkan dibubarkan koperasi Indonesia, salah satunya karena tidak berlandaskan prinsip, nilai dan prinsip koperasi, pengelolaan koperasi yang tidak baik, pengelolaan keuangan dan sumber daya manusia yang belum baik, serta kurangnya partisipasi anggota karena kurangnya pendidikan koperasi. Alasan paling umum yang dihadapi koperasi Indonesia adalah kurangnya modal usaha, yang juga disebabkan oleh kurangnya disiplin administrasi anggota dan kemitraan yang dibangun oleh koperasi.

Kementerian Koperasi dan UKM menargetkan pada tahun 2021 mampu mencetak 100 koperasi modern dan mendorong sebanyak 2,5 juta usaha mikro bertransformasi menjadi sektor Official. Ciri dari usaha mikro antara lain belum terdata dan memiliki perencanaan bisnis dengan baik.. Pemerintah terus mematangkan alternatif pengembangan untuk UMKM dan Koperasi yang murah, dan cepat agar UMKM ikhlas. rasio kewirausahaan menjadi $3.55 \%$, menaikkan rasio kredit perbankan di atas $20 \%$, serta kemitraan strategis antara UMKM dan usaha besar (Kemenkeu.go.id, 2021). Menurut Machmudi (2020). Kementerian Koperasi dan UKM menyiapkan dana alokasi khusus (DAK) fisik dan nonfisik tahun ini sebesar Rp200 miliar untuk digunakan pelatihan dan pendampingan koperasi serta usaha mikro, kecil, dan menengah (UMKM). Maka dari itu pemanfaatan dukungan dari pemerintah harus dimanfaatkan dengan sebaik nya dan terarah untuk tujuan program pemerintah untuk pelatihan dan pemberdayaan. Pelatihan adalah metode pembelajaran dan pengembangan terorganisir yang memperluas efisiensi individu, kelompok, dan organisasi (Rosmayati, 2021). Pengembangan menyebutkan pencapaian yang mengarah pada perolehan kemampuan dan keterampilan baru untuk pertumbuhan pribadi pegawai. Selain itu, biasanya sulit untuk menentukan eksplorasi pemberdayaan koperasi yang tepat untuk pelatihan, pengembangan, atau keduanya. Di sisa semua penilaian ini. Pelatihan adalah metode pembelajaran dan pengembangan terorganisir yang memperluas efisiensi individu, kelompok, dan organisasi (Suryana, 2006). Pengembangan adalah pencapaian yang mengarah pada perolehan kemampuan dan keterampilan baru untuk pertumbuhan pribadi pegawai (Ratnawati, 2015). Selain itu, biasanya sulit untuk menentukan apakah eksplorasi pemberdayaan koperasi yang tepat untuk pelatihan, pengembangan, atau keduanya.

\section{KAJIAN PUSTAKA}

\section{Program Pelatihan dan Pengembangan}

Menurut Hamalik (2007) menjelaskan bahwa bagian penting dari program pelatihan pegawai yang layak dibangun berdasarkan orientasi, keterampilan manajemen, dan keterampilan operasional pegawai. (Nudiati, 2006) menjelaskan bahwa program pengembangan pegawai harus 
terdiri dari keahlian inti, struktur yang sesuai di mana organisasi mengembangkan bisnis pegawai di tingkat perusahaan. Fungsi dasar pelatihan dan pengembangan adalah untuk memperoleh pengetahuan, kerja sama, pemikiran inventif dan pemecahan masalah pada organisasi koperasi (Wulandari \& Sulistari, 2018). Tujuan mendasar dari beberapa program pengembangan pegawai adalah untuk menyampaikan misi organisasi koperasi dan mendukung pekerja untuk mempelajari budaya organisasi (Savira \& Suharsono, 2013). Tujuan ini memberikan bantuan untuk tujuan strategis bisnis dengan memfasilitasi kesempatan belajar dan mendukung budaya organisasi (Rosmayati, 2021). Persyaratan untuk program pelatihan teknis bagi pegawai meningkatkan kepuasan kerja pegawai dan membantu untuk memahami budaya organisasi, yang mengarah pada keberhasilan organisasi. Manajer harus memperhatikan elemen-elemen ini sehingga pegawai harus diperbarui dengan pengetahuan pekerjaan saat ini. Pegawai akan lebih produktif, jika perusahaan memberikan pegawai pelatihan sesuai kebutuhan pekerjaan. Kita harus memperhatikan elemen-elemen ini sehingga pegawai harus diperbarui dengan pengetahuan pekerjaan saat ini. Pegawai akan lebih produktif, jika perusahaan memberikan pegawai pelatihan sesuai kebutuhan pekerjaan. Kita harus memperhatikan elemen-elemen ini sehingga pegawai harus diperbarui dengan pengetahuan pekerjaan saat ini. Pegawai akan lebih produktif, jika perusahaan memberikan pegawai pelatihan sesuai kebutuhan pekerjaan.

Saat ini sebagian besar organisasi telah membangun program yang berbeda untuk pelatihan dan pengembangan pegawai pegawai. Biasanya perusahaan menawarkan paket penggantian biaya pelatihan kepada pegawainya agar dapat meningkatkan pengetahuan dan keterampilan nya. Sesuai dalam UU No. 17 Tahun 2012 tentang Perkoperasin bahwa pegawai berhak atas tunjangan ini pendidikan dan pelatihan agar dapat memberikan dampak kerja yang baik. Akibatnya, banyak organisasi melakukan program pelatihan inhouse bagi pegawainya yang lebih bermanfaat dan murah. Bagian pelatihan organisasi berusaha untuk berkonsentrasi pada kecakapan kerja tertentu sedangkan pengurus perusahaan proaktif dengan pendekatan strategis tambahan. Program pelatihan dan pengembangan adalah komponen pendidikan yang direncanakan dan dengan metode yang luar biasa untuk berbagi budaya organisasi, yang bergerak dari satu keterampilan kerja untuk memahami keterampilan di tempat kerja, mengembangkan kepemimpinan, pemikiran inovatif dan pemecahan masalah. Program pengembangan pegawai mencakup berbagai teknik pengajaran, jadwal, dan lingkungan belajar yang membantu yang memastikan pegawai untuk meningkatkan keterampilan pegawai dan kemudian menerapkan pekerjaan pegawai (Thacker, 2002).

\section{Komponen Program Pelatihan dan Pengembangan}

Tidak ada metode khusus untuk mengembangkan pelatihan pegawai, namun metode yang tepat tertentu yang akan diukur. Program pelatihan dan pengembangan pegawai yang sempurna harus merupakan perpaduan antara pengetahuan, pengembangan karir, dan penetapan tujuan. Pendekatan-pendekatan ini akan menguntungkan program agar lebih bermanfaat bagi pegawai dan organisasi. Saat ini organisasi secara ekstensif menggunakan sistem Teknologi Informasi untuk program pembelajaran pegawai. Pengetahuan dan sistem informasi bergerak maju dengan cepat dan perusahaan-perusahaan itu tidak dapat bertahan hidup yang memberikan pengetahuan TI terkini kepada pegawai. Untuk tugas baru, pelatihan harus diberikan kepada pegawai agar dapat dengan mudah mengatasi tugas baru. Ini harus menjadi tanggung jawab organisasi untuk meyakinkan bahwa pegawai memiliki pengetahuan, keterampilan dan kemampuan, dan keterampilan ini harus sesuai dengan tingkat pekerjaan yang dibutuhkan. Selanjutnya, ketika pegawai membutuhkan keterampilan dan pengetahuan yang diperlukan, itu harus diberikan pada waktu yang tepat tanpa penundaan. Akibatnya, perusahaan dituntut untuk memastikan bahwa pegawai dapat belajar kapanpun pegawai butuhkan (Dwivedi, 2006).

Untuk menyelesaikan tujuan ini, organisasi membutuhkan segmen pembelajaran berbasis internet dan komputer agar organisasi koperasi tidak ketinggalan teknologi terkini. Alasan dasar perencanaan karir sebagai kuantitas program pelatihan pegawai tidak semata-mata untuk mendukung pegawai untuk berpikir bahwa pengurus koperasi membiayai karir pegawai, lebih lanjut perlu diingat bahwa pengurus membantu pegawai untuk mengelola berbagai karakteristik kehidupan pegawai dan jalur promosi yang jelas dalam bekerja. Pengurus koperasi tidak dapat menjanjikan pegawai untuk keamanan pekerjaan, tetapi pengurus memberi pegawai dalam kesempatan untuk meningkatkan pengetahuan dan keterampilan pegawai, sehingga pegawai dapat tetap bertahan dalam organisasi (Suryana, 2006). Pengembangan karir pegawai harus dibangun pada jalur karir yang cerah dimana pegawai dapat dengan mudah mengenali dan memberikan nilai. Untuk mencapai tujuan ini, pegawai harus mengklasifikasikan pekerjaan, prioritas kerja dan keterampilan saat ini yang pegawai miliki untuk 
melakukan pekerjaan pegawai. Karena itu, pegawai dapat mulai mengidentifikasi pekerjaan yang akan membutuhkan di masa depan dan serangkaian keterampilan untuk mengelola pekerjaan tersebut. Akibatnya, pegawai harus meningkatkan pemahaman untuk bekerja, akuntabilitas yang lebih baik untuk karir dan strategi tindakan untuk mencapai tujuan yang akan datang.

Masalah utama yang dialami oleh organisasi adalah melakukan praktik, yang mungkin membuat beberapa pegawai meninggalkan organisasi dan mencari lowongan pekerjaan tertentu di luar organisasi. Selain itu, terkadang pegawai merasakan risiko ukuran pegawai yang tepat dalam organisasi. Elemen kunci dari perencanaan karir dan pengembangan pegawai adalah penetapan tujuan. Oleh karena itu telah dijelaskan bahwa program pembelajaran mendukung pegawai untuk meningkatkan kinerja, bukan hanya meningkatkan kompetensi kerja (Nudiati, 2006). Lebih baik memberikan kesempatan kepada pegawai untuk melakukan pekerjaan pegawai dengan cara yang lebih baik dan jika pegawai membutuhkan bantuan, organisasi harus memberi pegawai alat yang tepat untuk melakukan pekerjaan itu. Program pengembangan membantu pegawai untuk belajar dan memfasilitasi pegawai untuk menjadi seorang berpikir kritis (Rizeria, 2018).

Pengetahuan dan keterampilan pegawai harus terus meningkat sehingga organisasi dapat membantu pegawai dengan cara membayar pegawai dengan gaji yang baik. Ini merupakan tanggung jawab utama organisasi untuk memberikan kesempatan kepada pegawai akan tetapi individu harus mengambil inisiatif untuk menggunakan kesempatan tersebut untuk kemajuan karir sebagai investasi jangka panjang (Hamalik, 2007). Program pelatihan dan pengembangan pegawai harus dibuat sedemikian rupa sehingga tidak hanya mencapai tujuannya tetapi memiliki konsekuensi optimis pada pegawai dan organisasi. Organisasi yang menggunakan program pengembangan pegawai mendapatkan hasil positif dari individu dengan menggunakan program ini.

\section{Manfaat Individu dari Program Pelatihan dan Pengembangan}

\section{Kompetensi Karir}

Pegawai koperasi mendapatkan banyak manfaat dari program pelatihan dan pengembangan pegawai. Pegawai mempelajari keterampilan non teknis dan teknis seperti yang dipersyaratkan oleh pekerjaan pegawai. Dalam 30 tahun terakhir pengangguran berada pada tingkat terendah yang tidak menguntungkan bagi pekerja untuk memulai pekerjaan baru, jika peluang untuk pertumbuhan lebih sedikit (Wulandari \& Sulistari, 2018).
Lulusan perguruan tinggi sebagian besar mempertimbangkan untuk perusahaan yang menyediakan program pelatihan intensif kepada pegawai, tetapi ide ini berisiko bagi organisasi untuk kehilangan pegawai baru yang terlatih. Program pengembangan pegawai membantu pegawai untuk bertahan dalam bekerja dan mengembangkan kemampuan pegawai untuk mengatasi teknologi baru. Program pengembangan pegawai membantu pegawai untuk bertahan hidup di masa depan dan mengembangkan kemampuan pegawai untuk mengatasi teknologi baru. Profesional muda dengan ambisi kewirausahaan tahu bahwa pegawai kekurangan pengalaman dan uang; maka pegawai mencoba untuk bergabung dengan perusahaan yang menyediakan program pelatihan untuk mempersiapkan pegawai pegawai untuk masa depan yang lebih baik. Program pengembangan pegawai membantu pegawai untuk bertahan hidup di masa depan dan mengembangkan kemampuan pegawai untuk mengatasi teknologi baru.

\section{Kepuasan Pegawai}

Perusahaan yang menyediakan program pelatihan dan pengembangan bagi pegawainya mencapai tingkat kepuasan pegawai yang tinggi dan perputaran pegawai yang rendah (Rosmayati, 2021). Pelatihan meningkatkan kehandalan organisasi karena pegawai menyadari pengeluaran organisasi pegawai dalam karir masa depan pegawai. Loyalitas dengan organisasi tidak dapat dihitung tetapi sangat penting untuk penghargaan intrinsik yang dirasakan pegawai. Pegawai merasa nyaman dan ingin bertahan dengan organisasi pegawai, ketika pegawai ditempatkan sesuai dengan keterampilan nya. Pegawai yang puas dengan pekerjaannya, percaya bahwa pekerjaannya memiliki tujuan dan penting bagi organisasinya. Biasanya pegawai yang berkinerja sudah baik tidak meninggalkan pekerjaan untuk tujuan keuntungan finansial. Meskipun gaji dan tunjangan memainkan peran penting dalam memilih dan mempertahankan pegawai, pegawai selalu mengamati peluang untuk memperoleh keterampilan baru, untuk mendapatkan tugas yang berbeda, dan mencari pengembangan pribadi dan profesional kerja pada diri mereka. Oleh karena itu, memfasilitasi dalam membentuk kepercayaan diri, harga diri dan kepuasan kerja pada pegawai merupakan hal terpenting apabila pegawai berkompeten dalam bekerja memiliki kepuasan tersendiri bagi pegawai dalam organisasi (Dwivedi, 2006).

\section{Kinerja Pegawai}

Efek pelatihan pada perilaku pegawai dan keterampilan kerja pegawai yang menghasilkan peningkatan kinerja pegawai dan perubahan konstruktif lebih lanjut yang berfungsi sebagai 
peningkatan kinerja pegawai (Gerosa, 2015). Pelatihan mempengaruhi kinerja pegawai pelatihan di tempat kerja mengarah pada keterampilan baru yang unggul. Keterampilan teknis dan profesional sangat penting bagi pegawai untuk melakukan pekerjaan dengan cara yang efektif. Memberikan kesempatan pelatihan kepada pegawai dapat meningkatkan kinerja pegawai. Mengacu pada penemuan, pelatihan meningkatkan pengetahuan kerja dan keterampilan kerja.

\section{Manfaat Organisasi dari Program Pelatihan dan Pengembangan}

\section{Pertumbuhan Pasar}

Program pengembangan pegawai penting bagi organisasi mana pun untuk tetap bertahan dan kompetitif di pasar khususnya unit koperasi. Meskipun mahal bagi organisasi untuk memberikan pelatihan kerja, tetapi investasi ini positif bagi organisasi untuk mempertahankan pegawai nya di tempat kerja. Pertama pengurus mengidentifikasi nilai pelatihan dan dapat dipasarkan oleh organisasi menjadi keunggulan koperasi dan kedua pengurus koperasi memahami bahwa seberapa cepat informasi ditransfer dalam lingkungan bisnis saat ini. Menurut Hamalik (2007) menjelaskan bahwa organisasi dituntut untuk mengembangkan dan memelihara lingkungan belajar bagi pegawai yang memperluas pengetahuan organisasi dan kemampuan bersaing. Namun, program pelatihan pegawai diperoleh dengan biaya yang tinggi, tetapi berdampak positif pada pengembalian investasi. Terakhir, organisasi dapat memanfaatkan program pelatihan dan pengembangan pegawai untuk meningkatkan keterampilan pegawai.

\section{Kinerja Organisasi}

Pelatihan telah didefinisikan sebagai faktor utama yang berkontribusi terhadap efektivitas organisasi. Eksplorasi pada topik ini merekomendasikan bahwa investasi dalam program pelatihan dan pengembangan dapat dibenarkan dan berdampak yang diciptakannya terhadap efektivitas individu dan organisasi yang dikembangkan menjadi meningkat (Savira \& Suharsono, 2013). Selanjutnya, penelitian sebelumnya telah menyebutkan hubungan sebab akibat antara pelatihan dan efektivitas organisasi (Nudiati, 2006). Menurut Rahayu (2011) merekomendasikan bahwa salah satu gangguan yang biasanya bermasalah untuk diidentifikasi, adalah mengusulkan perhitungan kinerja organisasi yang efektif. Sedarmayanti (2017) mendukung ini dengan menjelaskan bahwa kurangnya data yang sesuai dan kesulitan metodologis mencegah penilaian yang memadai dari dampak apresiasi modal manusia dan kinerja organisasi. Namun, ada faktor yang meningkat bahwa praktik manajemen sumber daya manusia berdampak pada sikap dan perilaku yang berhubungan dengan pekerjaan. Untuk mengevaluasi efektivitas program pelatihan dan pengembangan disarankan untuk memeriksa secara langsung hubungan pelatihan dan komitmen organisasi. Selanjutnya telah terungkap sebagai keterkaitan dengan efisiensi organisasi (Soetjipto, 2014).

Kinerja dan sikap yang berhubungan dengan pekerjaan yang konstruktif terutama bergantung pada persepsi pegawai karena pegawai berpikir bahwa organisasi menjaga pegawai. Namun, faktor yang sama dapat diandalkan dengan model pertukaran sosial.. Namun pelatihan dapat digunakan untuk mendapatkan hasil yang disukai yang mungkin mengandung komitmen organisasi yang dapat meningkatkan kinerja. Penelitian ini mengusulkan bahwa fasilitas program pelatihan dan pengembangan kemungkinan diambil persetujuan oleh pegawai bahwa organisasi pegawai perlu memasuki pertukaran sosial dengan pegawai. Perjanjian pertukaran sosial ini menghasilkan ikatan psikologis yang tahan lama antara pegawai dan organisasi (Trihargo, 2019).

\section{Retensi Pegawai}

Retensi pegawai adalah gagasan yang menantang dan tidak ada metode khusus untuk mempertahankan pegawai dengan organisasi. Beberapa organisasi telah mengungkapkan bahwa salah satu karakteristik yang membantu mempertahankan pegawai adalah dengan menawarkan pegawai kesempatan untuk meningkatkan pembelajaran pegawai. Oleh karena itu, telah dikonfirmasi bahwa ada hubungan yang kuat antara pelatihan dan pengembangan pegawai, dan retensi pegawai (Rosmayati, 2021). Perusahaan harus menyadari bahwa pegawai yang berpengalaman adalah aset penting dan perusahaan harus menanggung tantangan untuk mempertahankan pegawai. Oleh karena itu, perusahaan yang memberikan program pelatihan dan pengembangan kepada pegawainya berhasil mempertahankan pegawai. Trihargo (2019) banyak pegawai yang berpartisipasi dalam program pelatihan pegawai tidak yakin akan hubungan konvensional antara program dan retensi pegawai beberapa manajer menemukan bahwa suasana belajar yang positif diarahkan pada tingkat retensi yang lebih tinggi.

Organisasi yang menawarkan program pengembangan pegawai semakin sukses dengan mempertahankan pegawai. Rancangan program pelatihan yang efektif juga dapat meningkatkan retensi di antara pegawai. Retensi pegawai adalah gerakan sukarela oleh organisasi untuk 
menciptakan lingkungan yang melibatkan pegawai untuk jangka panjang. Untuk deskripsi retensi yang lebih efektif, peneliti telah merekomendasikan bahwa organisasi dapat berisi program pelatihan dan pengembangan yang mengklasifikasikan tugas, persyaratan, dan harapan sukarelawan. Untuk mempertahankan pegawai, organisasi perlu berpikir serius tentang investasi pegawai dalam pelatihan dan pengembangan. Meskipun banyak orang yang terlibat dengan program pelatihan dan pengembangan pegawai tidak yakin akan hubungan langsung antara program dan retensi pegawai (Gerosa, 2015). Namun, sejumlah manajer tertentu menemukan bahwa lingkungan belajar yang konstruktif menunjukkan tingkat retensi yang lebih tinggi (Rizeria, 2018).

\section{METODE PENELITIAN}

Menurut Sugiyono (2018) Peneliti menggunakan metode studi kepustakaan dan observasi sebagai metode yang mendukung untuk melengkapi data yang tidak peneliti dapatkan melalui wawancara. Penelitian ini merupakan penelitian kualitatif dengan desain studi bersifat deskriptif mengenai "Program Pelatihan dan Pengembangan serta Manfaatnya bagi Pegawai dan Organisasi Koperasi" yang dihasilkan dari kepustakaan dan observasi yang telah peneliti lakukan.

\section{Hasil Penelitian}

Fakta-fakta dalam penelitian saat ini dapat dimanfaatkan dalam berbagai cara yang beragam oleh keragaman organisasi. Pendapat penting adalah bahwa perusahaan pada dasarnya menempatkan nilai tertinggi pada pegawai pegawai, dan mengembangkan keyakinan dan praktik yang menunjukkan komitmen tertinggi dari pegawai. Pegawai membutuhkan perasaan seperti pegawai menghasilkan modifikasi penting untuk kesuksesan perusahaan dan memberikan hasil dan niat positif untuk melakukan pekerjaan pegawai dengan baik. Selain itu, sulit bagi sebagian besar perusahaan untuk mengembangkan institusi tingkat perusahaan dan memberikan kesempatan yang luas untuk promosi internal, tetapi mudah bagi organisasi untuk membantu pegawai pegawai dalam membuat tujuan karir dan rencana aksi untuk pengembangan karir pegawai. Organisasi tertentu mungkin menemukan bahwa pegawai mengembangkan pegawai yang menerapkan kemampuan dan keterampilan untuk organisasi lebih lanjut, namun organisasi juga menemukan bahwa pegawai meningkatkan rasa loyalitas dari pegawai lain. Dalam studi ini terdapat dukungan yang substansial bagi individu dan organisasi untuk mendapatkan beberapa manfaat dari program pelatihan koperasi. Benefit tersebut mengandung efisiensi dan faktor-faktor yang berhubungan langsung maupun tidak langsung dengan kinerja pegawai. Studi ini telah mengumpulkan dukungan untuk hasil positif dari program pelatihan untuk organisasi. Manfaat ini terdiri dari kinerja organisasi yang lebih baik (misalnya, profitabilitas, efisiensi, dan output) dan manfaat lebih lanjut yang secara langsung atau tidak langsung terkait dengan kinerja pegawai. namun organisasi juga menemukan bahwa pegawai meningkatkan rasa loyalitas dari pegawai lain. Dalam studi ini terdapat dukungan yang substansial bagi individu dan organisasi untuk mendapatkan beberapa manfaat dari program pelatihan. Benefit tersebut mengandung efisiensi dan faktor-faktor yang berhubungan langsung maupun tidak langsung dengan kinerja pegawai. Studi ini telah mengumpulkan dukungan untuk hasil positif dari program pelatihan untuk organisasi. Manfaat ini terdiri dari kinerja organisasi yang lebih baik (misalnya, profitabilitas, efisiensi, dan output) dan manfaat lebih lanjut yang secara langsung atau tidak langsung terkait dengan kinerja pegawai. namun organisasi juga menemukan bahwa pegawai meningkatkan rasa loyalitas dari pegawai lain. Dalam studi ini terdapat dukungan yang substansial bagi individu dan organisasi untuk mendapatkan beberapa manfaat dari program pelatihan.

Organisasi-organisasi yang mampu mengenali manfaat pelatihan yang diakui dalam studi ini mampu menjauh dari mengamati tujuan pelatihan sebagai fungsi operasional. Misalnya, organisasi koperasi telah menurunkan jasa pinjaman dan menaikan unit usaha nya berarti koperasi berfokus pada pelatihan kentang kewirausahaan nya agar dapat berkembang, namun dengan meningkatkan investasinya pengeluaran dalam pelatihan ini. Manajer organisasi ini memilih pengetahuan dan informasi mengenai hasil bisnis yang bersangkutan untuk membuat kesimpulan tentang bagaimana menetapkan sumber daya termasuk sumber daya dengan cara pelatihan. Pelatihan adalah metode yang menekankan pada cita-cita dan budaya organisasi yang membantu, termasuk kemajuan karir, pemotongan dan pembatasan moneter, lingkungan yang sangat kompetitif, dan filosofi yang digerakkan oleh pasar (Suryana, 2006). Jelas mencatat manfaat program pelatihan dan perencanaan, penyampaian, dan evaluasi dengan memanfaatkan informasi yang terlibat dalam penelitian ini akan memungkinkan manajer manajemen sumber daya manusia untuk menjadi organisasi strategis dan menjauh dari saran yang tidak diinginkan.

\section{SIMPULAN DAN SARAN}

\section{Simpulan}

Dalam studi ini kami mengambil fakta pengamatan bahwa pelatihan mengarah pada manfaat penting bagi individu dan organisasi. Analisis literatur yang 
ada mengusulkan bahwa manfaat ini bervariasi dari kinerja individu dan organisasi. Untuk memahami manfaat program pelatihan dan pengembangan, Dalam studi kepustakaan ini menerapkan tingkat dan perspektif disiplin yang berbeda dari program pengembangan pegawai. Dalam penelitian ini, peneliti juga mengamati langsung, bagaimana meningkatkan manfaat pelatihan khusus nya di lingkungan Dekopinda Kota Cimahi. Pengamatan tersebut antara lain memberikan perhatian pada desain pelatihan, penyampaian, dan transfer pelatihan. Setelah menyelesaikan studi tentang topik ini, peneliti sangat percaya bahwa pelatihan sangat bermanfaat bagi organisasi untuk mengembangkan program pengembangan pegawai. Jika ada program pelatihan dan pengembangan yang sistematis bagi pegawai koperasi merupakan keuntungan koperasi dan tetap kompetitif di pasar kerja. Program pengembangan yang terorganisir dan efisien dengan pengelola koperasi yang mendukung akan sangat membantu organisasi untuk mempertahankan sumber daya manusia yang paling berharga, terutama pegawai yang memiliki banyak pengalaman dengan organisasi. Jika organisasi mampu mendukung semua pegawai dalam memenuhi kebutuhan pegawai maka baik pegawai maupun organisasi akan mendapatkan manfaat jangka panjang. Juga sangat penting bagi organisasi untuk mengevaluasi secara tepat waktu keberhasilan program pelatihan dan pengembangan pegawai. Program pengembangan yang terorganisir dan efisien dengan pengelola koperasi yang mendukung akan sangat membantu organisasi untuk mempertahankan sumber daya manusia yang paling berharga, terutama pegawai koperasi yang memiliki banyak pengalaman dengan organisasi. Jika organisasi mampu mendukung semua pegawai dalam memenuhi kebutuhan pengurus maka baik pegawai maupun organisasi akan mendapatkan manfaat jangka panjang. Juga sangat penting bagi organisasi untuk mengevaluasi secara tepat waktu keberhasilan program pelatihan dan pengembangan pegawai.

\section{Saran}

Dalam penelitian ini memberikan saran untuk peneliti selanjutnya diharapkan dapat mengidentifikasi instruksi khusus untuk penelitian yang akan datang. Pertama, peneliti mengusulkan bahwa manfaat pelatihan mungkin memiliki efek positif seperti sebagai manfaat pegawai individu, yang kemudian mempengaruhi hasil organisasi. Namun, penelitian diperlukan untuk mengenali dampak yang memungkinkan kelancaran transfer manfaat pengembangan pegawai pada tingkat yang berbeda. Kedua, ada kesenjangan yang ada antara literatur terapan dan akademik mengenai penggunaan waktu siklus sebagai faktor untuk mengukur kegunaan program pelatihan dan pengembangan. Besarnya dampak pada kualitas kinerja koperasi mungkin tidak sama dalam organisasi dan menerapkan solusi untuk masalah baru. Diperlukan penelitian mengenai faktor-faktor yang dapat meningkatkan kesadaran akan manfaat pelatihan dan pengembangan pada berbagai tahap eksplorasi. Penelitian ini mungkin mendapatkan bantuan dari primer studi tentang efek pelatihan dan pengembangan pada kebaruan dan kemampuan beradaptasi kinerja pegawai dan organisasi. Ketiga, sementara karakter afeksi telah diakui dalam jumlah reaksi terhadap pelatihan dan pengembangan dalam proses pelatihan dan pengembangan secara umum.

\section{DAFTAR PUSTAKA}

Djamaludin. (2010). Pengembangan Koperasi dan Dampaknya terhadap Kesejahteraan Anggota Melalui Kinerja dan Pelayanan Koperasi Dengan Metode Canonical Correlation. Ilmu Ekonomi Universitas Borobudur, 87-111.

Dwivedi, A. (2006). Merancang Pelatihan Partisipatif Untuk Pemberdayaan.

Gerosa, V. (2015). Pengaruh pendidikan dan pelatihan serta partisipasi anggota terhadap motivasi berkoperasi cu pancur kasih bengkayang. 1-15.

Hamalik, O. (2007). Manajemen Pelatihan Ketenagakerjaan: Pendekatan Terpadu (Cet.4).

Kemenkeu.go.id. (2021). Ini Serangkaian Upaya Pemerintah agar Usaha Mikro Naik Kelas dan Koperasi Modern Tumbuh. https://www.kemenkeu.go.id/publikasi/berita/i ni-serangkaian-upaya-pemerintah-agar-usahamikro-naik-kelas-dan-koperasi-moderntumbuh/

Machmudi, M. I. Al. (2020). Kemenkop Siapkan Rp200 Miliar untuk Pelatihan UMKM. https://mediaindonesia.com/ekonomi/305330/k emenkop-siapkan-rp200-miliar-untukpelatihan-umkm

Nudiati, D. (2006). Pengelolaan Pelatihan Kewirausahaan Sebagai Sistem Pembelajaran dalam Persiapan Masa Pensiun. Tesis. Bandung: Pendidikan Luar Sekolah. Bandung: Pendidikan Luar Sekolah, Universitas Pendidikan Indonesia.

Rahayu, S. T. (2011). Transformasi Organisasi, Studi Kasus Pada Semarang Growth Centre. Jurnal Dinamika Sosial Ekonomi, Volume 7, Nomor 2, Halaman 215 Dan 216.

Ratnawati, E. S. (2015). Mengelola Sumber Daya Manusia Pada Koperasi Wanita (Penilaian 
Kinerja Kopwan Berdasarkan Aspek Organisasi). September.

Rizeria, R. (2018). Peranan pendidikan dan pelatihan pegawai dalam pengembangan industri kecil dan menengah pada dinas perindustrian, perdagangan, koperasi dan ukm kabupaten kutai. Jurnal Administratif, 6(4), 153-164.

Rosmayati, S., \& Maulana, A. (2021). Kepuasan Kerja Dan Motivasi Kerja Menjadi Variabel Prediktor Kinerja Karyawan. 1(1).

Savira, F., \& Suharsono, Y. (2013). Strategi Pengembangan Sumber Daya Manusia Di Dinas Koperasi Ukm Dan Tenaga Kerja Kabupaten Tasikmalaya. Journal of Chemical Information and Modeling, 01(01), 16891699.

Sedarmayanti. (2017). Manajemen Sumber Daya Manusia.

Soetjipto, D. (2014). Road to Semen Indonesia, Transformasi Korporasi Mengubah Konflik Menjadi Kekuatan.

Sugiyono. (2018). Metode Penelitian Kuantitatif, Kualitatif, dan $R \& D$.

Suryana, A. (2006). Panduan Praktis Mengelola Pelatihan.

Thacker, B. dan. (2002). Effective Training: Systems, Strategies, and Practices (Second Editions).

Trihargo, G. (2019). Manajemen Risiko dalam Digital Transformation Era 4.0.

Wulandari, M., \& Sulistari, E. (2018). Strategi Pengembangan Koperasi (Studi Kasus Pada Koperasi Simpan Pinjam Mentari Dana Mandiri Salatiga). UKSW Salatiga, 1, 1-6. 